\title{
Tool development to understand rural resource users' land use and impacts on land type changes in Madagascar
}

Lena M. Reibelt!, Gabrielle Moser", Anne Dray", Ihoby H. Randriamalalal, Juliette Chamagne", Bruno Ramamonjisoall', Luis Garcia Barrios'v, Claude Garciall,v, Patrick O. Waeber',II

\begin{abstract}
A majority of Madagascar's rural people depend on the primary sector. The country's agricultural hub, the Alaotra-Mangoro region, is mainly tied to fisheries and rice production. Increasing human population and decreasing output from fisheries and agriculture are pushing the rural resource users further into the protected marshlands. Understanding rural farmers' decisions can help developing improved management plans to support long-term functioning of (socio-) ecological systems. We present here an example of inter- and transdisciplinary research which uses a participatory modelling approach to develop a shared vision of the Alaotra socio-ecological system. The purpose of this study is to introduce the used gaming approach in detail by documenting the process of co-construction of the Alaotra wetlands' conceptual model. We then describe how the model is transcribed into a table-top role-playing game that will help researchers and stakeholders alike explore and understand decisions and management strategies. We finally report on first outcomes of the game including land use decisions, reaction to market fluctuation and landscape change.
\end{abstract}

\section{RÉSUMÉ}

La majorité des populations rurales de Madagascar dépendent du secteur primaire. Le centre agricole du pays, la région d'AlaotraMangoro, est principalement lié à la pêche et à la production de riz. L'accroissement de la population humaine et la baisse de la production agricole et de la pêche poussent les utilisateurs des ressources rurales vers les marais protégés. Comprendre les décisions des agriculteurs peut aider à développer de meilleurs plans de gestion pour soutenir le fonctionnement à long terme des systèmes (socio-) écologiques. Nous présentons ici un exemple de recherche interdisciplinaire et transdisciplinaire qui utilise une approche de modélisation participative pour développer
Correspondence:

Lena M. Reibelt

Madagascar Wildlife Conservation

Lot 17420 bis Avaradrova Sud, 503 Ambatondrazaka, Madagascar

Email: reibelt.lena@gmail.com

une vision partagée du système socio-écologique d'Alaotra. Le but de cette étude est de présenter en détail l'approche des jeux utilisée, en documentant le processus de co-construction du modèle conceptuel pour les zones humides d'Alaotra. Nous décrivons ensuite comment le modèle est transcrit dans un jeu de rôle sur plateau qui aidera les chercheurs et les parties prenantes à explorer et à comprendre les décisions et les stratégies de gestion. Nous présentons enfin les premiers résultats du jeu, y compris les décisions d'utilisation des terres, la réponse aux fluctuations du marché et aux changements des paysages.

\section{INTRODUCTION}

A majority of Madagascar's rural people depend on the primary sector. One of the most important agricultural production areas in Madagascar is the Alaotra-Mangoro region (Figure 1). The primary economic driver in the region is tied to fisheries and rice production, providing one third of the country's rice output (Andrianandrasana et al. 2005, Ferry et al. 2009). The human population of the two lake districts of the Alaotra-Mangoro region has increased from 110,000 people in the 1960s to over 710,000 in the 2000s (Monographie Régionale Alaotra-Mangoro 2012), with increasing land area being titled or occupied (Jacoby and Minten 2007); consequently, land is becoming scarce, forcing many people into the marshes to establish rice fields (Ratsimbazafy et al. 2013, Waeber et al. 2017).

A majority of the marshland fringing the lake has already been converted to rice production (Ranarijaona 2007, Ratsimbazafy et al. 2013), with 100,000 ha outputting ca. 300,000 t per year. A particular problem in the whole of Madagascar is deforestation and land clearing (mostly through slash and burn swidden agriculture, called tavy). The marshlands, Alaotra's 'forests', are also in continuous decline (Ratsimbazafy et al. 2013). Studies and observations using remotely sensed imagery have further

\footnotetext{
I Madagascar Wildlife Conservation, Lot 17420 bis Avaradrova Sud, 503 Ambatondrazaka, Madagascar

II ETH Zurich, Ecosystems Management, Forest Management and Development Group, Universitätsstraße 16, 8092 Zurich, Switzerland

III ESSA Forêts, BP 175, Ankatso, Antananarivo 101, Madagascar

IV ECOSUR, El Colegio de la Frontera Sur Unidad San CristÛbal. Carretera Panamericana y Perifèrico Sur S/n, Barrio Marìa Auxiliadora, CP 29290 San Cristûbal de Las Casas, Chiapas, Mexico

V UR Forêts et Société (F\&S), Département Environnements et Sociétés du CIRAD, Campus International de Baillarguet, 34398 Montpellier Cedex 5, France.

Citation Reibelt, L. M., Moser, G., Dray, A., Randriamalala, I. H., Chamagne, J., Ramamonjisoa, B., Garcia Barrios, L., Garcia, C., Waeber, P. O. 2017. Tool development to understand rural resource users' land use and impacts on land type changes in Madagascar. Madagascar Conservation \& Development XX, XX: XX-yy. http://dx.doi.org/10.4314/mcd.wetlands.3 // Early View
} 


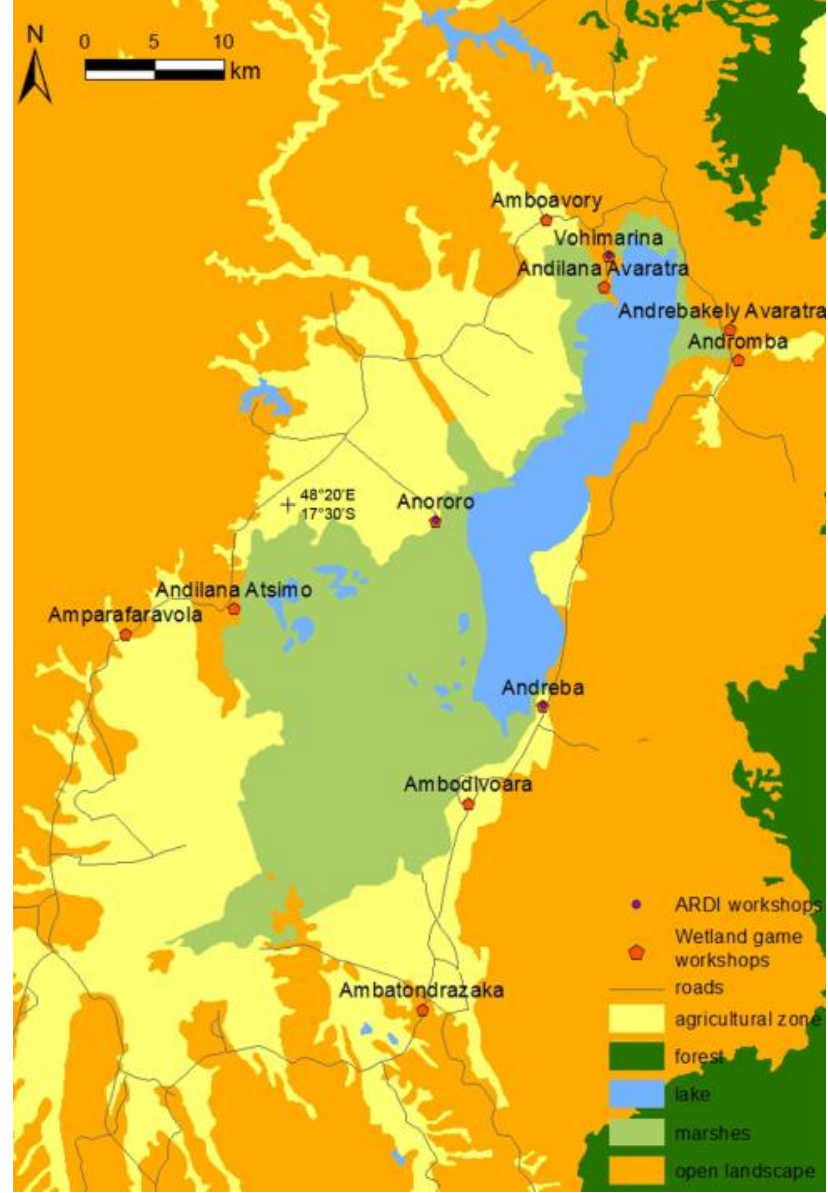

Figure 1. The geographic boundaries of the Alaotra socio-ecological system considered in this study.

shown that Lake Alaotra had shrunk to $20 \%$ of its former size in 2000; in addition, crop productivity in the basin is reputed to have dropped to about $40 \%$ of its former level as a consequence of river and irrigation canal silting, yet clear-cutting and tavy continue in the Alaotra-Mangoro region (Wright and Rakotoarisoa 2003, Bakoariniaina et al. 2006). It is broadly recognized that due to low yields, clear cutting and land clearing are used to expand areas under cultivation as well as for livestock, creating a self-reinforcing cycle between declining yields and continued deforestation and land transformation.

Understanding rural farmers' decisions can help develop improved management plans to support long-term functioning of (socio-) ecological systems. We present here an example of interand transdisciplinary research which uses a participatory modelling approach to develop a shared vision of the Alaotra socio-ecological system (SES, henceforth real SES). In this context, the creation of mechanistic models and boundary objects (e.g., games; White et al. 2010, Akkerman and Bakker 2011) are used in conjunction to help stakeholders navigate the complexities of a landscape in transition, and explore the multiple (social, ecological and economical) dimensions of the outcomes their individual decisions will generate. To help stakeholders and decision makers become aware of the complex interactions and feedback loops as well as allowing them to explore the current, expected, and potentially surprising behaviours of the territory they are managing, we developed a transdisciplinary landscape approach based on the Companion Modelling ComMod (Etienne 2014). The ComMod approach merges modelling, the development of boundary ob- jects (toy models such as role-playing games) and stakeholder engagement processes.

The purpose of this study is to describe this gaming approach in detail: (i) we first document the process of co-constructing the conceptual model of the Alaotra wetlands environment in an interactive, iterative, and incremental manner. We then (ii) describe how the conceptual model is transcribed into a table-top role-playing game that will serve as boundary object, allowing stakeholders to play with it and helping researchers and stakeholders alike explore and understand decisions and management strategies. We (iii) report on first outcomes of the game; what are players' land use decisions? How is the landscape changing? In addition, how are participants reacting to changing market conditions?

\section{CO-CONSTRUCTION OF A CONCEPTUAL MODEL}

Our methodology to collectively construct the conceptual model of the Alaotra wetlands region builds upon a dedicated participatory modelling method developed by Etienne et al. (2011). This method, called ARDI, constitutes a framework to help identify the main components and drivers of change in a given natural resources management setting. It encourages different stakeholders to elicit their mental models of the system, and allows for co-constructing a common representation of the issues at hand, after agreeing on those most striking in a given context. Unfolding the method, the research team can identify together with the stakeholders the main Actors, Resources, Dynamics and Interaction (hence the acronym ARDI) that are relevant to the system under analysis and the agreed-upon issue(s).

In the Alaotra context we ran four full-day ARDI workshops in an iterative and incremental way (cf. Souchère et al. 2010) over a period of 10 months (April 2013 to February 2014). A total of 35 fishers and farmers from the Alaotra participated in these workshops; participants were approached randomly by our local research assistants at respective village markets and invited to join the research sessions. The first step in ARDI was to collectively formulate and agree on the 'burning' issues at stake in the marshland system. As a starting point, we offered the phrase "the marshes are changing" to present a neutral formulation and to avoid judgments or imposing constraints to further discussions. The derived research question was "What is driving the changes observed in the Alaotra marshes?". In the next steps, the participants of the ARDI workshops collectively identified and ranked (cf. Bernard 2006) actors that are important in driving change in the marshland system. The four main types of actors in the real SES identified during the workshops are fishers, farmers, migrants, and collectors (Figure 2). The term 'collector' is a broad description for the people in the supply chain that are placed between producers and markets. Information on the main wetland resource users' characteristics was validated through the stakeholder typology study by Rakotoarisoa et al. (2015). The same ranking exercise as for the main actors was applied to identify the main resources which are used, modified or traded by the actors in the real SES. Important resources identified relating to marshland change were money, fish, food, rice and cattle. In a final step, the participants agreed on the interactions between the actors and resources, while describing the temporal and spatial dynamics of these linkages. The most important interactions were farming (rice and vegetables), fishing, and buying or selling products at the market. 
After each ARDI workshop, a summary was prepared by the research team, which was then presented to the next ARDI workshop participants, new to the process. This allowed incremental modification and verification of each previous conceptual mind map. After the fourth workshop, the ARDI results were complemented and triangulated with five focus groups (professional fishers, men only; onion farmers, women only; villagers who also practice fishing, mixed group; reed cutters, women only; and medicinal plants collectors, mixed group) that were held in the same period with a total of 30 resource users (same selection approach as for the ARDIs). Additional insights from the focus groups together with archival research from the Ministries of Fisheries, Agriculture, and Environment, allowed the verification and clarification of open questions that had emerged during the ARDI workshops. The final result was the conceptual model shown in Figure 2.

\section{GAMIFICATION}

'TRANSLATING' THE CONCEPTUAL MODEL TO A RPG. Role

Playing Games (RPGS) in Companion Modeling can be fully computerized RPGs (agent based models), computer supported RPGs, or table-top RPGs, depending on the research context. As the game workshops were to take place in a rural setting around Lake Alaotra, with oftentimes no access to electricity, we opted for a computer-supported table-top role-playing game (henceforth RPG), as opposed to a computer-based game. The combination of participatory workshops with focus groups allowed the development of a shared vision of the socio-ecological system in the Alaotra, i.e., the main actors, resources, dynamics, and interactions that play a role in 'marshland changes' (Figure 2). These components and relationships, i.e., the conceptual model, served as the backbone to construct the RPG. Actors and resources identified in the conceptual stage were converted into players' profiles (Farmers; note that game components henceforth will be indicated by capitalisation) or institutions (Market with Collector, Bank) while resources were materialized through tokens or activity cards (Farming: Onion, Rice, Vegetable; Fishing; Hunting; Logging; Mining). The interactions and associated verbs from the conceptual model prompted the sequence of actions in the game, while processes and dynamics such as land-type changes were trans-

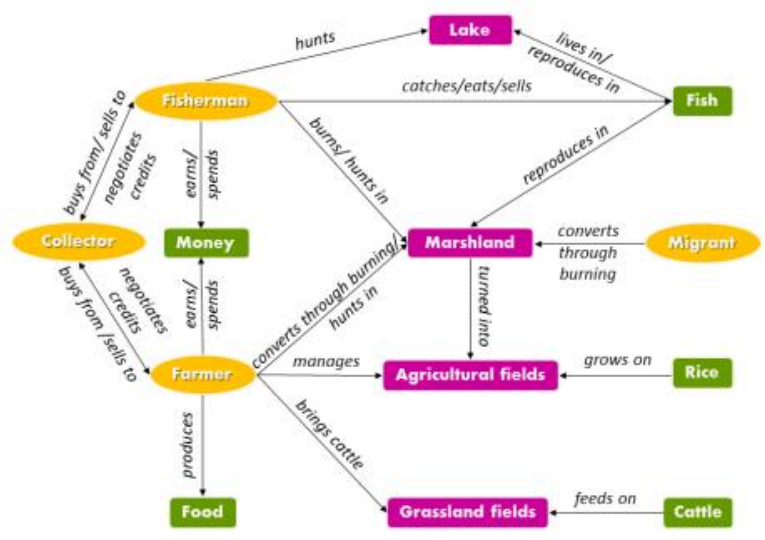

Figure 2. Conceptual model stemming from four ARDI workshops (Etienne et al. 2011) that encapsulates the elements that were common across the four locations, except for the onions as explained above (hence the use of the term 'farmer', which can represent either rice or onion farmer, or both). In green are the resources, in pink the zones, and in yellow the actors. lated into rules and course of the game (details in the 'How to play the game' section).

For the gaming process (Figure 3), the research team decided to track both individual and summarized activities. We introduced a Personal Game Sheet where each player can keep track of personal decisions (activities) and cash income. Additionally, cumulative impacts of individual decisions and changes are monitored on a game board at the end of each round, where landscape cover types change depending on individual agricultural activities (e.g., Marshes turn into Agriculture land-type). This allows players to track their individual decisions and see whether there are knockon effects, but also to experience the summarized results and consequences of their individual decisions on the game board. The game board shows the Landscape, which is a simplified and archetypal representation of the various land cover types to be found in the Alaotra region (Figure 1). From the basin to higher altitude these are the Lake, Marshes, Agriculture zone (baiboho in Malagasy, called mailles by Ducrot and Capillon 2004), Open landscape (representing the tanety, which is Malagasy for hilly slopes, dominated by grass species, cf. Kull 2012, Kull et al. 2013), and Forests (Figure 1, Figure 3). The landscape stratification representing all these zones was adapted from Husson et al. (2012).

Productivity in the real SES is highest in the agriculture zone, followed by marshes and open landscape; productivity in the game has accordingly been parameterized and calibrated proportionally based on statistics available from the Regional office, and is a proxy for soil fertility and water availability. The resource users (fishers, farmers) in the real SES are pursuing more than just one livelihood supporting activity (Rakotoarisoa et al. 2015). As the players in the game are the main actors found in the real SES, they can do as many activities as they can afford in each zone (at least four land-type-based activities per round are mandatory to ensure that the game process will last over six rounds). In the Agriculture zone however, where all land is already occupied, a maximum of one activity per game round and player is allowed; this is a proxy

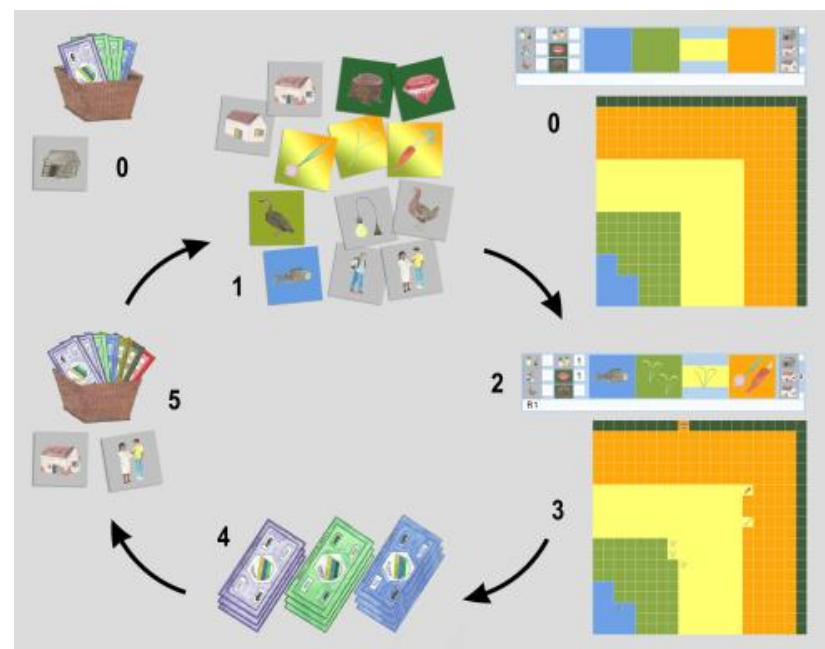

Figure 3. Table top model (role-playing game RPG). (0) Starting conditions, with Personal Cash Box and a Bronze House (lowest housing level); Personal Game Sheet; and Landscape where all changes will be shown. The game order is to (1) invest your money at the Market in: land-based action tokens (Fishing in the Lake, Hunting in the Marshes (light green), Onion/ Rice/ Vegetable Farming in either Marshes/ Agriculture zone (yellow)/ Open landscape (orange), or Rosewood logging or Sapphire mining in the Forest (dark green); players can also invest into Quality of Life: Electricity, Education, Protein, Health, or improve their House (silver or gold level); (2) track your spatial decisions on your Personal Game Sheet: where do you do what and how many of the purchased activities?; (3) place your land-based tokens on the Landscape to follow changes; (4) get your output calculated at the Bank; and (5) receive your earned money. R1= round one; in total there are six game rounds. 
for increasing (over-) population. Apart from land-based activities, players can also invest into compost, a proxy for technology, into Quality of Life (QoL), i.e., parameters such as Electricity, Education, Health and Protein, as well as the possibility to invest into improved Housing (from bronze to silver or gold standard; this decision cannot be undone in later game rounds). These parameters (Figure 3) are ways to track players' values and preferences.

During the course of the game, all players make decisions on how to pursue their livelihoods, and then cash the output at the Bank. A member of the research team represents the Bank and uses a computer to collect all the decisions tracked on each player's Personal Game Sheet in an Excel working sheet. The Bank thus is a central place where all individual decisions are entered in a data sheet (Supplementary Material S1), and the production returns are calculated and cashed. Returns depend on the type, and frequency of the chosen activities and the zone. Returns can also be modified by the arrival of a Collector to the Market, or a Gendarme. Gendarmes are represented by the research team and stand for law enforcement in the real SES; in the game they represent the risk of illegal activities (Hunting in the Marshes, or Mining and Logging in the Forest). These so-called 'opportunity activities' come with a risk and opportunity cost: the Gendarmes might 'catch' the players and issue them fines (represented as a random process calculated in Excel). While the potential arrival of a Gendarme or the risk of a fine is not communicated, the players know that in the real SES these three activities are illegal, and participants assumed that these were also illegal activities in the game. All three illegal activities occur in the real SES: bushmeat hunting in the marshes, e.g. Hapalemur alaotrensis, a nationally and internationally protected lemur species (cf. Rakotoarivelo et al. 2011) and rosewood logging or sapphire mining in the humid forests of Madagascar (Randriamalala and Liu 2010, Innes 2010, Allnutt et al. 2013, Stoudmann et al. 2017). At the Bank, production return for Fishing stands as proxy for fish stock which varies with the number of actors fishing and number of actors farming in the Marshes, i.e., converting Marshes into the Agriculture zone land type, as these are crucial for fish reproduction (Wallace et al. 2015, 2016). In the game, the Bank also functions as a credit institution for actors needing cash for investing into future activities (this mechanism was introduced to avoid non-participation in game rounds and as a means to borrow money without further affecting the interactions between players).

Translating the conceptual model and scientific evidence into game components and rules resulted in a game (Figure 3), which represents an implicit reality. It is important to note that the game does not 'rebuild' reality, but is a model, and as such a simplification of reality allowing to explore and analyse livelihood strategies. Being a simplification of the actors, resources and space relevant to the Alaotra stakeholders, the players recognize their reality in the game.

GAME CRASH TESTS. After actors, resources, and interrelations had been 'translated' into a draft game, further gamification was undertaken as an iterative development process based on 10 crash-test workshops until we reached saturation, i.e., no new items were suggested to be added or removed from the game. One session was with game specialists and researchers in Montpellier (France), two sessions with conservationists in Antananarivo and Ambatondrazaka (Madagascar), one session with primary school teachers, and six sessions with resource users around Lake Alaotra (Madagascar). In total, over 60 people participated in this game testing and verification phase. The main changes compared to the conceptual mind map (Figure 2) were (i) the exclusion of 'zebu cattle', not deemed relevant in the game context by local stakeholders (it had been included in the conceptual model due to its importance as a working tool and status symbol, but players did not make use of it as it was irrelevant for the game setting), (ii) the inclusion of Forest to complement the landscape, since some of the Alaotra stakeholders also used to frequent forests for livelihood purposes. It was further agreed that 'population growth' (or overpopulation) will be implicitly included in the game by adding a restriction to the most fertile zone of the landscape (the so-called Agricultural zone); also, for simplicity, and to allow participants to play themselves (as farmers/ fishers, regardless of whether their status was local resident or migrant), it was decided to leave out 'migrants' as additional actors in the game.

HOW TO PLAY THE GAME. There are six rounds (R) to a game; a round can represent a year or a season, however this is not pre-defined and the players can decide what works best for them. The game was calibrated for five players, it was run and facilitated by 3-4 Malagasy research team members from the Alaotra region, including helping illiterate players, while the calculations at the 'Bank' were done by the senior author. A typical game round has the following structure: (1) players go to the Market to invest into activities and Quality of Life (QoL) tokens; (2) track their decisions on the Personal Game Sheet; (3) put their tokens on the Landscape; and (4) go to the Bank where their production output is calculated; and (5) cashed (Figure 3, Figure 4).

In the following, each step is explained in more detail. (0) At the outset of the game, each player receives a start capital of 4,500 \$A (game money) and basic housing; to track decisions, each person has a Personal Game sheet and the joint Landscape. (1) At the Market, the players have different options about how to invest their money; the respective prices are displayed at the Market. The activities include (i) land-type based activities such as Fishing (500 \$A as one-time investment for a boat), Farming of Rice, Onion, or Vegetable (500 \$A each); (ii) opportunity activities such as Hunting, Mining, and Logging (150 \$A, respectively); (iii) Compost to increase productivity and thus return from Farming (200); (iv) QoL such as Health, Education, Proteins, or Electricity (300 \$A, respectively), and ( $V$ ) three levels of Housing $(500,700$, or $1000 \$ A$ to be paid at the end of each round as a proxy for living costs). Players purchase the game tokens that represent the activities they decide to do. (2) On their Personal Game Sheet players track their decisions, i.e., which activity they do in which zone. This is done with stickers or written abbreviations in the respective cells of the Personal Game Sheet. (3) As a next step, players go to the collective game board, the Landscape, where they put their purchased tokens and can see how individual decisions scale up to a collective impact, i.e., how aggregated individual decisions can induce system change. The unit of a land-based activity is the cell (represented as squares; Figure 3). The original land-types can change when activities are done on them; for example Marshes (light green) or Open landscape (orange) gets transformed into Agriculture zone (yellow) when Farming is undertaken in these landtypes (Farming in the Agriculture zone itself will not change the land-type). A Forest cell (dark green) will turn into Open landscape (orange) when Mining or Logging takes place. Fishing is only done 


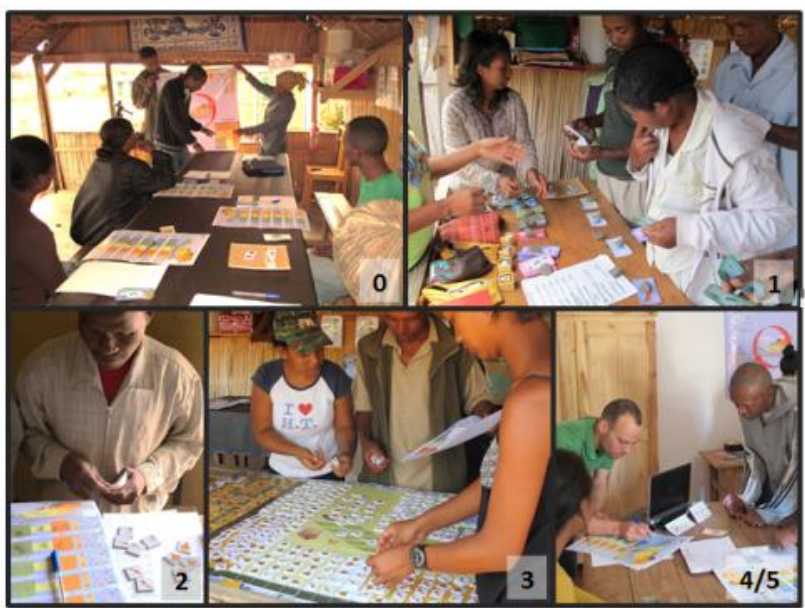

Figure 4. Pictures of the gaming session course as described in Figure 3. (0) Explaining the game to players; (1) players investing into activities at the Market; (2) Tracking decisions on the Personal Game Sheet; (3) Implementing decisions on the Landscape; (4/5) Bank calculating output which is then cashed.

in the Lake and does not invoke a land-type change, while Hunting in the game is restricted to the Marshes. The research team and players together change the land-types manually according to each player's Personal Game Sheet decisions. Additionally, there is a Table of Change (ToC) monitoring agricultural activity in the Marsh, Open landscape and Forest; for each activity in the Marshes, a token on the Table of Change is flipped, showing different symbols of biodiversity such as the Alaotran gentle lemur (Hapalemur alaotrensis), the White-faced Whistling Duck (Dendrocygna viduata), and the marsh plant Cyperus sp. The Table of Change is used to track land-type change and to serve for discussions during the debriefings after the game sessions. (4) At the end of each round, players go to the Bank where their activities are entered into an excel sheet to calculate the revenue of their activities. (5) Players receive their cash from the Bank. Then the next game round begins.

SCENARIOS. Participants in the game play the role of resource users who have to secure their livelihood and wellbeing, i.e., maintain or increase their Personal Cashbox and QoL. We did not predefine what a livelihood strategy could be or what well-being and QoL means for the players, since we hoped to gain insights concerning these through the gaming behavior of the participants (viz. physical model representing the real SES).

We played two scenarios. In scenario 1, the game approach was 'business as usual', i.e., players could decide which activities to pursue. In the second half of scenario 1 (rounds 4-6), a Collector appeared on the Market (represented by a member of the research team) to promote either Onions or Vegetables. The Collector on the Market was a representation of externally induced change and fluctuation of prices (i.e., of production returns). The Collector brought new money into the virtual SES, shifted demand and made the production return of specific products (Onion or Vegetables, i.e., the one that had been planted less before) substantially more attractive than in the first half of the game.

A second scenario of "disturbances" had the exact same rules as scenario 1, except that at the end of each round, there was an event card drawn by a player representing a disturbance. In total, there were 10 cards with five different disturbances; two climatic events (cyclone, drought); fire; and two disease events (onion, rice). These events affect the landscape in different zones, and have different severities, but all modulate the total production outcome. In contrast to scenario 1, there was no market change taking place in order to better track the possible impacts of the disturbances on game outcomes and players' strategies.

\section{SERIOUS GAMING RESULTS}

PARTICIPANTS. We held a total of 15 RPG workshops, with

five local actors per workshop from around Lake Alaotra. The participants of the RPG workshops were randomly selected, while meeting the following criteria: (i) typical resource user with livelihood activities within the wetlands of the Alaotra, (ii) living close to Lake Alaotra; (iii) aged between 20-70 years old to ensure that all participants were still working for their livelihoods, and (iv) a gender balanced participation. The sample was comprised of 33 women and 42 men, with an average age of 44 years (range 23-67); they represented average households of five members. Main real-life livelihood activities were farming (83\%) and fishing (19\%). Mean years of schooling were 8.7 (range 0-15). In addition, we played three RPG sessions with a total of 15 decision makers, representing the Ministries of Agriculture, Fisheries, Water and Forest, Topography, and Livestock.

LAND-BASED ACTIVITIES AND LANDSCAPE CHANGES. We used exploratory data analysis to gain an overview of the 30 variables derived from the gaming. After collecting summary statistics, we used either the t-test or the Wilcoxon Rank Sum test to make comparisons between different groups of participants. The Mann-Whitney $U$ test was used when dealing with non-normally distributed variables. All analysis was done in $\mathrm{R}$, with versions ranging from 3.0.3 to 3.2.1. The significance level used for all hypothesis testing was $\alpha=0.05$ unless stated otherwise.

The majority of activities in scenario 1 was farming ( $41 \%$ rice vs. $25 \%$ onion vs. $23 \%$ vegetable farming; Figure 5). After the first half of the game, a change of investment behavior occurred, i.e., $43 \%$ of participants changed their primary crop from rice to onion or vegetables, or some combination of the three. This coincided with the arrival of a Collector on the Market. Significantly less farming activities were done in the first half of the game (R1-3) Vs. the second half (R4-6), also when comparing the separate farming activities (for example rice vs. rice, or onion vs. onion; all pairs with $p<0.0001$, Wilcoxon Rank Sum test) which also coincided with the market change (the arrival of a Collector). The various zones were targeted differently, with most activities undertaken in the Open landscape (Figure 6), despite its lower fertility. Significantly more farming activities were undertaken on the Open landscape compared to the Marshes ( $p<0.0001$, Wilcoxon Rank Sum test). Considering the non-land-based activities, the investment in technology also increased during the course of the game (being strongly correlated with monetary variables, i.e., player's gain, investment, and total ownership). In contrast, the investment in Quality of Life parameters declined until R4, before rising again. Housing improved during the game, being associated with gain (all investments are detailed in Figure 5).

In the RPG, a majority of land-based activities were performed in the Marshes and the Open landscape since the Agriculture zone was already occupied (only allowing for a single activity per player and game round). In this context, landscape change was the sum of agricultural activities in the Marshes and Open landscape (Figure 7). During the first three rounds, the pace of landscape change was slower than during the last three rounds (cf. steeper slopes, mainly for the Open landscape), which implies 


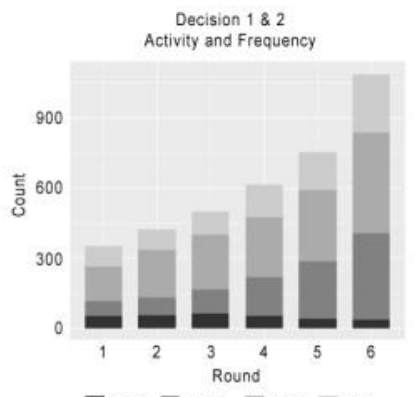

Fish Onion
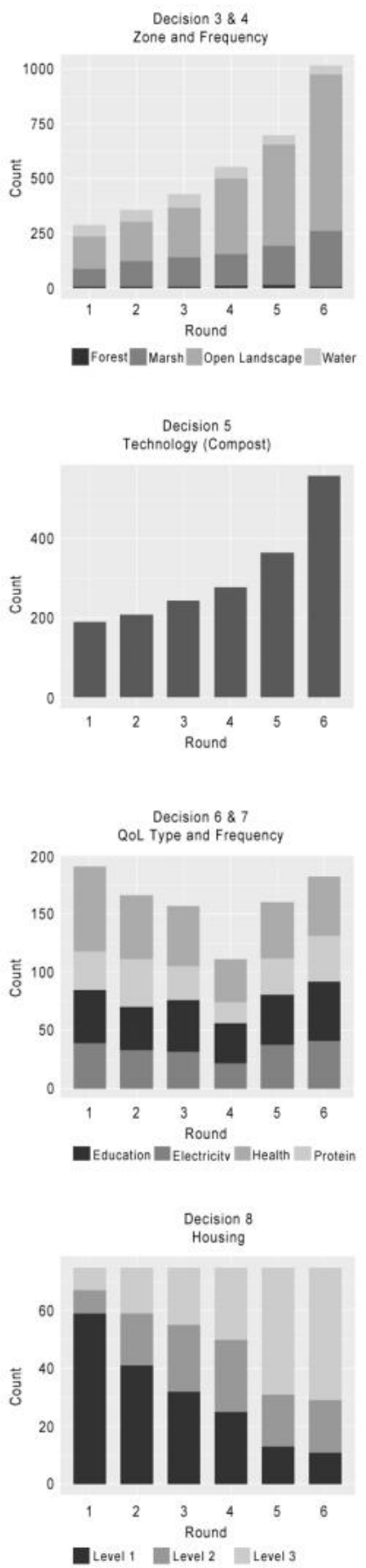

Figure 5. Decision tree. Chain of decisions that a player has to make during a game round. Graph 1: land-based activities such as fishing or onion or vegetable farming; Graph 2: zoning, where in the landscape have been done the land-based activities; Graph 3: How much compost (a proxy for technology) has been used; Graph 4: Quality of life investments, Graph 5: Housing types as proxy for living costs (from $1=$ basic to $3=$ high quality).
60

40

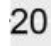

20

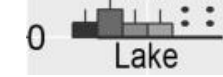

$\frac{11}{1}:$ :ake

Figure 6. Spatial zoning ( $x$-axis) and frequency of livelihood activities (y-axis). Box and whisker plots for total activities per zone. Testing for differences in median values between rounds using the Wilcoxon Rank sum test $(n=75)$. Agricultural zone is not shown since there was a structural restriction in the game (one activity per player and round) to mimic land titling and occupancy. Significantly more farming activities were performed compared to opportunities $(p<0.0001$ Wilcoxon Rank Sum test-farming median 6, opportunities median 0), which included Hunting, Mining and Logging (all opportunities in this model are illegal activities).

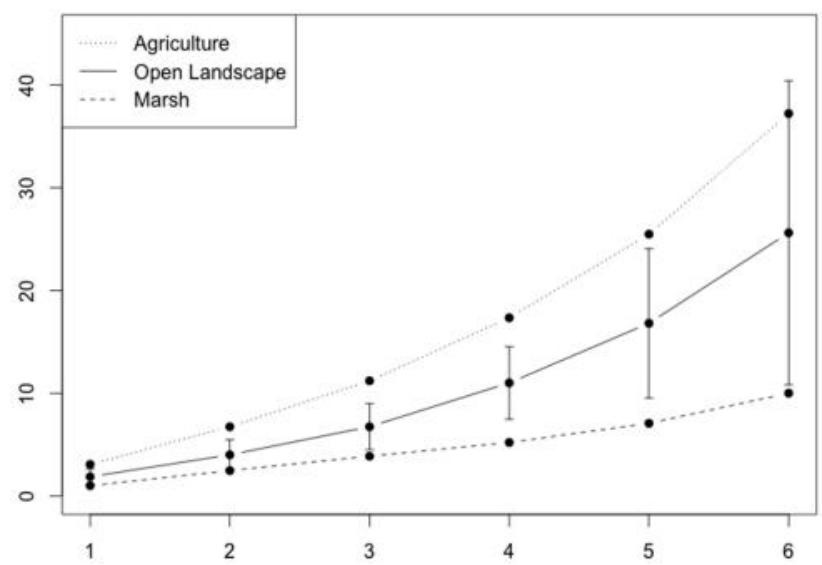

Figure 7. Landscape changes. Slopes of changing land types (Marshes vs Open landscape) and converted land into Agriculture zone (the cumulative curve of Marshes + Open landscape units). We calculated the median for each round ( $\mathrm{x}$ axis) of each activity for each RPG game workshop (GW1-7, GW9-16; $n=75)$. Then we calculated cumulative change for each of the 15 games and the slope

between each set of rounds for those cumulative change graphs. The slope in this graph was calculated as $(y 2-y 1) /(x 2-x 1)$, where each set of coordinates comes from the cumulative change plot at each different round. Finally, the mean (and standard deviation for Open landscape) of the slopes over all games was calculated and plotted. We used a t-test for testing between rounds (1-2 vs 2-3, $2-3$ vs $3-4$, etc.) and found that there is a significant difference in slope: for Agriculture between rounds ( 1 vs 2$)$ and ( 2 vs 3$)(p-v a l=0.04699)$ and for Open landscape between ( 2 vs 3 ) and ( 3 vs 4 ) ( $p$-val $=0.01017$ ). The $x$-axis denotes the rounds; the $y$-axis shows frequency of activities. 
the Landscape as a whole experienced an increasing speed of transformation, and hence that land conversion into Agriculture zone was increasing.

Globally, those who had more money (a threshold above the median $=5525$ \$A [game money] in the Personal Cashbox) invested in more than double the amount of total activities (approximately 12) than those who had less money (less than or equal to the median) (approximately 5) -Wilcoxon rank sum test, $p<0.0001$. We found that the cumulative land-type change for R1-3 was significantly lower than for R4-6 for all activities (t-test, all p-values less than 0.002).

BRIDGING VIRTUAL AND REAL SES. When using RPGs for research, the most important phase of the research starts once the game sessions are accomplished. Debriefings help to bridge game behavior and real life decisions, to identify and discuss similarities and differences and to explain decisions. The importance of this research phase is reflected in the saying that 'the learning starts when the game stops' (Crookall 2010, Garcia et al. 2016). Thus, three questionnaires (one before the gaming session, one right afterwards, and one after two weeks) were administered, covering topics such as gaming behaviour and real-world livelihood strategies, the meaning of markets, and landscape change (Table 1).

After the workshop, the players could take home their Personal Game Sheets with their tracked decisions (while the researchers had tracked all decisions through the Bank, i.e., Microsoft Excel 2010 calculations). We assumed that people continued to think about the game after the workshops. Two weeks later, we conducted detailed face-to-face interviews with all parti- cipants in order to further bridge the virtual and real world, i.e., comparing players' decision made in the game with their realworld background.

All phases of our research, from the development of the conceptual model, to the gamification process, and the actual RPG sessions followed the recommendations of ethical code of conduct provided by Wilmé et al. (2016). This also includes obtaining prior informed consent from each participant, and assuring anonymity and confidentiality. A general feedback from our research participants of the game workshops (including the game development workshops) was that they appreciated a platform where they were able to discuss their real life issues revolving around agricultural development, livelihood concerns, and conservation and environmental values, without having to fear consequences from the authorities.

\section{DISCUSSION}

This study describes the tool development process of a serious role-playing game (RPG), which served to explore rural resource users' land use decisions and related impacts on land type changes in the Alaotra region in Madagascar. The research is placed in a common pool resource context (sensu Ostrom 2009) where a continuously growing human population in a finite landscape strives for increased food security, and a minimum level of well-being and quality of life (Rendigs et al. 2015). In such a world, the interactions within the social system and the ecological systems become increasingly complex. The RPG model represents and combines the most important components of the social system (Farmers/Fishers, Market, Collector, Bank) and the ecological system (spatial zones such as Lake, Marshes, Open Landscape,

Table 1. Exemplary participants' statements collected during the game debriefing sessions on questions concerning land use decisions, reaction to market fluctuations and landscape change. Baiboho means 'agriculture zone'; zetra means 'marshlands'; tanety stands for 'open landscape'. The questions are as follows: Q1: What are your strategies? Did you change them and why? Q2: Did you change your activity after the promotion [market change]? Q3: In the game, what changes do you see on the landscape, looking at all zones? Q4: In reality, what are the changes that you can observe in each zone? Q5: In real life, do you or would you use the zetra if the revenues were high?

Questions Exemplary answers

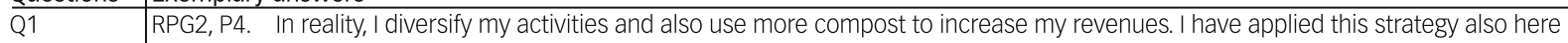
in the game.

RPG3, P5. I have increased my activities since the revenues were good and I had cash to invest.

RPG6, P5. Though I do not have much education, I use my knowledge on how to fish or plan my activities. Even if the fishing output is getting less and less, I continue to do fishing since I do it in my real life too.

Q2 $\quad$ RPG1, P1: I have changed to vegetables due to the promotion. But to make sure to survive I have continued investing into other activities as well.

RPG2, P2. I have changed my activities, since everybody else in the game did. Also, the promotion made me invest more into vegetables.

RPG2, P1. I do always rice; just a little bit of vegetables. The promotion does not always bring good things, so I better stuck to rice, and increase rice activities, and I was right; I had more revenues.

RPG5, P5. In real life, I do everything, even if I do not know how to do, but I do an effort, and if I see that it brings good revenues then I continue.

Q3 $\quad$ RPG1, P2. The majority of people practice the counter season rice [in the marshes], since it brings more cash in comparison to the other zones, and since in the baiboho there is not enough space for more than one activity, and the tanety is not as productive.

RPG1, P2. In the game, because we all did fishing, the lake is full of fish tokens, and the revenue is little; but we all need to survive.

Q4 $\quad$ RPG3, P5. The tanety is affected by fires, and baiboho is becoming sandier due to erosion, which also progresses the destruction of the zetra. The fish stock is decreasing due to increased numbers of fishers and illicit fishing.

RPG4, P1. Cultivation on tanety is decreasing due to infertility of the soils and because it is still difficult to use kibota [tractor] on tanety. Hence, people push into zetra for cultivation; also it is still very humid and good growing conditions. We do use zetra to feed our families

RPG7, P3. The total destruction of the environment due to human overexploitation; also climate change is affecting the water balance

RPG11, P3. The human population is increasing continuously. People need more land, hence the zetra is disappearing. People are not aware or do not think of consequences and do not protect the zetra.

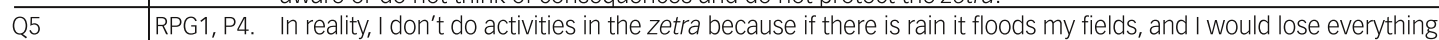

RPG3, P4. We would like to use the zetra, but I won't do it because it requires quite some effort and material; also, it means destroying the zetra and our lives are then endangered. Also, I still have enough land for agricultural production, and I prefer to improve the per unit output there.

RPG6, P4. It is our goal to become rich; hence I continue to increase my activities, even in the zetra if needed.

RPG7, P2. This depends on the law. If it was not illegal, then I'd do it. 
Forest; but also the Fish stock) in order to explore resource users livelihood decisions. The majority of stakeholders involved in the wetland RPG workshops are the regular resource users that directly depend on the land by pursuing activities in agriculture, fisheries, cattle farming and forests. In the real Alaotra SES they are the 'actors of change'. Change at the landscape level is induced by the cumulative decisions of rural resource users. Even if making a chain of spatially and temporally smaller decisions, they transpose and manifest in the form of bigger changes at the landscapes or watershed level. Change here is more than simply the sum of all decisions, since there are linkages and feedback loops in both the ecological and social systems (Le et al. 2012). The gaming approach allows players to experience these individual and up-scaled changes by tracking them on their Personal Game Sheets and the common game board, i.e., the Landscape.

It is important to note that the wetland RPG and the players' decisions do not necessarily mirror reality, but allow the researchers to observe the participants' decision making during the games and to use it as an entry point for discussion and reflection. The debriefing sessions after the gaming are hence the crucial part, as they allow to make comparisons between game behaviour and real life, and to reveal motivations or values that determine decisions in everyday life. Our results show that the majority of participants have played the game as they act in real life. Still, some mentioned that they fished or cultivated vegetables even though they do not do so in real life; congruency of game behaviour and real life ranged between 50 and $100 \%$. Interestingly, while some players kept doing the same activities during the whole game session, others tried different strategies and reacted to market change or neighbours' successful strategies. Independent from external circumstances, a majority would always continue to cultivate rice (or others fishing) because it is central to both their culture and livelihood. Players reacted differently to this whole system perspective; for example, once players realized that the fish stocks were collapsing, some started shifting their activities towards more agriculture, while others went on as before. The latter did so because for them "fishing is part of our culture"; or, because "fishing is a quality of life". A majority of players invested into rice activities, because "it is the staple food of the Malagasy", or because "it is our habit", reflecting the central aspect of the real SES. Players noted that both in the game as well as in reality, fisheries output decrease due to increasing numbers of fishermen and resulting overexploitation. They also acknowledged the increasing occupation of the grasslands and marshes for agricultural activities (see also Ratsimbazafy et al. 2013). They referred to increasing population numbers and decreasing output per unit as being the reasons for the ongoing agricultural extensification.

The exemplary debriefing statements reveal different strategies of the players. In the game, as well as in reality, some stick to the activities they have been doing for years. They thus do not react to change or externalities, and continue with their traditional land uses, regardless of the external conditions. In opposition, some players/ resource users tried out different options and continued with the most successful or promising ones; similarly, in real life, they adapt quickly to change and know to use and potentially benefit from opportunities, sometimes by taking risks; they are responsive to market change and adapt their activities quickly and accordingly. Some players observe others' strategies and implement them once they see their success. Study participants acknowledged the changes occurring in the Alaotra landscape. With increasing population pressures (both population growth and migration) and decreasing outputs in agriculture and fisheries, people are in search for (easily accessible) alternatives. While some acknowledged the ecological importance of the marshes for ecosystem functioning, or would not touch the marshes because they are legally protected, others do already use them to increase their income. It is suggested that with increasing pressures on peoples' livelihoods, more and more individuals will decide to transform marshland to expand their fields for better agricultural output.

The game behaviour and corresponding debriefing answers also showed that the more cash was available in the SES, the more investment into farming activities were undertaken. In contrast, Quality of Life parameters did not follow this pattern. Further analysis is needed to clarify whether this indicates a prioritization of physical and financial capital above human and social capital, or whether this behaviour resulted from game design (e.g., in contrast to Housing, there were no different levels achievable for the QoL parameters). Players scarcely used opportunity activities since the risk of paying a fine was judged as being too high. In addition, players generally performed few activities solely in the forests as these, in reality, are too far away from their daily working space. Vicinity to, or contact to, resources matters, as shown in two studies in the region where attitudes and perceptions of resource users towards lemurs and the special conservation zone Park Bandro changed with distance (Reibelt et al. 2017, Waeber et al. 2017). These patterns were also confirmed during the debriefing discussions. An interesting finding is that the more money there is in the virtual SES, the faster the landscape is transformed (in the game, this was through increased investments into agricultural activities). During the debriefings, players also stated that if they had more money in real life they would have many more fields of onion or rice for productions, herewith referring to extensification of farming. However, in the game participants would also invest into better technology to increase their production output, which refers to agricultural intensification. In the real SES, however, both options are hampered: the best arable land is already occupied and space within a legal context is already scarce, while farmers barely have the means to invest into better agricultural technologies. What participants also wish for is more governmental support to inform them about new technologies.

After the third gaming round, with the arrival of the Collector (i.e., market change through the promotion of vegetables or onions), a significant shift in agricultural activities appeared. Many participants stated that they used Round 1 of the game as a learning process, and then started to strategize their activities, which again were mainly prompted by real-life experiences and backgrounds. Participants stated that they followed the Collector because they were either curious, or they needed to change their activities to earn more income, thus taking a risk; while others changed because they observed and followed other players' success. Such debriefing statements allow the identification of stakeholders' management strategies, which have the potential to inform policy decisions for an increased resilience of the agricultural sector.

Such information is urgently needed, since increased drought periods and decreasing output further put pressure on farmers and the rural population alike, who directly depend on rice. In addition, the political instability at the national level has caused an increase in market prices for the staple food rice (Randrianja 
2012). The holistic approach pursued in the RPG and the results obtained allow the support of cross-sectorial and trans-boundary decision support and policy making. The regional governing institutions (e.g., Ministry of Environment, Ecology and Forest, Ministry of Agriculture, Ministry of Fisheries) can take the main actors' behavioural response into consideration but also farmers' different levels of vulnerability to changes for future management plans and thus increase the resilience of the socio-ecological system of the Alaotra region. As stated in the modified Environmental Charter (Loi n²015-003), one of the objectives, inter alia, is to " (...) reconcile the people with their natural environment...for a sustainable development...through a green economy". Hence, policies need to take into consideration which types of activities are performed within which type of ecosystem. Changes potentially bear transition costs (North and Wallis 1994); in the Alaotra context, change or outside forces are also steering the farmers to change their livelihood strategies (Copsey et al. 2009a, b, but see also Waeber and Wilmé 2013). This often comes at the cost of biodiversity. In order to make the SES more resilient, policy making needs to create a framework that allows the buffering of market changes, which oftentimes are instilled by political changes at the uber-regional level. In the Alaotra, current trends, also shown in the RPG, indicate a clear 'bias' towards rice. System resilience in this context means allowing the future of the Alaotra SES to change trajectory and shift towards a scenario of more 'ecological agriculture', which should favour the introduction of agricultura intensification over current extensification trends, allowing space for biodiversity.

\section{ACKNOWLEDGMENTS}

We acknowledge the support from Kiady Rakotondravoninala (Regional Director of the Ministry of Environment, Ecology, Sea and Forests), Samuel Razafindrabe (Regional Director of the Ministry of Agriculture) and Herilalaina Andrianantenaina (Regional Director of the Ministry of Fisheries). We also thank our local research assistants, Toky, Sambatra, Alida, and Sanda for their support and enthusiasm during all the game sessions. We further thank all participants of crash-tests and serious game sessions for their trust and participation in this study. For the game development crash-tests, we further thank the Communauté de Pratique des Concepteurs de Démarches Participatives in Montpellier, France; Missouri Botanical Garden Madagascar; Durrell Wildlife Conservation Trust Madagascar; and the Teachers from the public primary schools around Lake Alaotra. We would like to thank Lucienne Wilmé (MBG) for contributions to game structure and design, Andry Fitiavana Rakotondranisa (MWC) from Andreba Gare for the drawings, Fabian Schroer for graphic creation, and Natasha Stoudmann (ETH) for the English editing. This research was funded by the Swiss Programme for Research on Global Issues for Development under the research grant IZ01Z0_146852 as part of the AlaReLa Alaotra Resilience Landscape project.

\section{REFERENCES}

Akkerman, S. F. and Bakker, A. 2011. Boundary crossing and boundary objects. Review of Educational Research 81, 2: 132-169. <http://dx.doi.org/10.3102/0034654311404435>

Allnutt, T. F., Asner, G. P., Golden, C. D. and Powell, G. V. 2013. Mapping recent deforestation and forest disturbance in northeastern Madagascar. Tropical Conservation Science 6:1-15
Andrianandrasana, H. T., Randriamahefasoa, J., Durbin, J., Lewis, R. E. and Ratsimbazafy, J. H. 2005. Participatory ecological monitoring of the Alaotra wetlands in Madagascar. Biodiversity \& Conservation 14, 11: 2757-2774. <http://dx.doi.org/10.1007/s10531-005-8413-y>

Bakoariniaina, L. N., Kusky, T. and Raharimahefa, T. 2006. Disappearing Lake Alaotra: Monitoring catastrophic erosion, waterway silting, and land degradation hazards in Madagascar using Landsat imagery. Journal of African Earth Sciences 44: 241-252. <http://dx.doi.org/10.1016/j.jafrearsci.2005.10.013>

Bernard, H. R. 2006. Research Methods in Anthropology: Qualitative and Quantitative Approaches. AltaMira Press, Walnut Creek, CA.

Copsey, J. A., Rajaonarison, L. H., Randriamihamina, R. and Rakotoniaina, L. J. 2009a. Voices from the marsh: Livelihood concerns of fishers and rice cultivators in the Alaotra wetland. Madagascar Conservation \& Development 4, 1: 25-30. <http://dx.doi.org/10.4314/mcd.v4i1.44008>

Copsey, J. A., Jones, J. P. G., Andrianandrasana, H. T., Rajanoarison, L. H. and Fa, J. E. 2009b. Burning to fish: local explanations for wetland burning in Lac Alaotra, Madagascar. Oryx 43, 3: 403-406.

<http://dx.doi.org/10.1017/\$0030605309000520>

Crookall, D. 2010. Serious games, debriefing, and simulation/gaming as a discipline. Simulation \& Gaming, 41, 6: 898-920. $<$ http://dx.doi.org/10.1177/1046878110390784>

Ducrot, R. and Capillon, A. 2004. A practice analysis to account for adoption of innovations in irrigated rice cropping systems in Lake Alaotra (Madagascar). Journal of Sustainable Agriculture 24, 3: 71-96. <http://dx.doi.org/10.1300/J064v24n03_06>

Etienne, M. (ed.) 2014. Companion Modelling, a Participatory Approach to Support Sustainable Development. Springer, Netherlands.

Etienne, M., Du Toit, D. R. and Pollard, S. 2011. ARDI: a co-construction method for participatory modeling in natural resources management. Ecology and Society 16, 1: 44. Available at <http://www.ecologyandsociety.org/vol16/iss1/art44/>

Ferry, L., Mietton, M., Robison, L. and Erismann, L. 2009. Le lac Alaotra à Madagascar-Passé, présent et futur. Zeitschrift fuer Geomorphologie 53, 3: 299-318. <http://dx.doi.org/10.1127/0372-8854/2009/0053-0299>

Garcia, C., Dray, A. and Waeber, P. 2016. Learning begins when the game is over: using games to embrace complexity in natural resources management. GAIA-Ecological Perspectives for Science and Society 25, 4: 289-291. $<$ http://dx.doi.org/10.14512/gaia.25.4.13>

Husson. O., Charpentier, H., Raharison, T., Razanamparany, C., Moussa, N. et al. 2012. SCV à proposer au Lac Alaotra et dans le moyen-ouest manuel pratique du semis direct à Madagascar. Volume II. Chapitre 2.1. $<$ http://agroecologie.cirad.fr>

Innes, J. L. 2010. Madagascar rosewood, illegal logging and the tropical timber trade. Madagascar Conservation \& Development 5: 6-10. $<$ http://dx.doi.org/10.4314/mcd.v5i1.57335>

Jacoby, H. G. and Minten, B. 2007. Is titling in Sub-Saharan Africa cost-effective? Evidence from Madagascar. The World Bank Economic Review 21: 461-485. <http://dx.doi.org/10.1093/wber//hm011>

Kull, C. A. 2012. Air photo evidence of historical land cover change in the highlands: Wetlands and grasslands give way to crops and woodlots. Madagascar Conservation \& Development 7, 3: 144-152. <http://dx.doi.org/10.4314/mcd.v7i3.7>

Kull, C. A., Carrière, S. M., Moreau, S., Ramiarantsoa, H. R., Blanc-Pamard, C. et al. 2013. Melting pots of biodiversity: tropical smallholder farm landscapes as guarantors of sustainability. Environment: Science and Policy for Sustainable Development 55: 6-16. <http://dx.doi.org/10.1080/00139157.2013.765307>

Le, Q. B., Seidl, R. and Scholz, R. W. 2012. Feedback loops and types of adaptation in the modelling of land-use decisions in an agent-based simulation. Environmental Modelling \& Software 27-28: 83-96. <http://dx.doi.org/10.1016/j.envsoft.2011.09.002>

Monographie Régionale Alaotra-Mangoro*. 2012. Unpubl. report. Direction Régionale de l'Économie Alaotra-Mangroro.

North, D. C. and Wallis, J. J. 1994. Integrating institutional change and technical change in economic history a transaction cost approach. Journal of Institutional and Theoretical Economics (JITE)/ Zeitschrift für die gesamte Staatswissenschaft 150, 4: 609-624. 
Ostrom, E. 2009. A general framework for analyzing sustainability of social-ecological systems. Science 325, 5939: 419-422. <http://dx.doi.org/10.1126/science.1172133>

Rakotoarisoa, T. F., Waeber, P. O., Richter, T. and Mantilla-Contreras, J. 2015. Water hyacinth (Eichhornia crassipes), any opportunities for the Alaotra wetlands and livelihoods? Madagascar Conservation \& Development 10, 3S: 128-136. <http://dx.doi.org/10.4314/mcd.v10i3.5>

Rakotoarivelo, A. R., Razafimanahaka, J. H., Rabesihanaka, S., Jones, J. P. G. \& Jenkins, R. K. B. 2011. Lois et règlements sur la faune sauvage à Madagascar: progrès accomplis et besoins du future. Madagascar Conservation \& Development 6, 1: 37-44. <http://dx.doi.org/10.4314/mcd.v6i1.68063>

Ranarijaona, H. L. T. 2007. Concept de modèle écologique pour la zone humide Alaotra. Madagascar Conservation \& Development 2, 1: 35-42. <http://dx.doi.org/10.4314/mcd.v2i1.44128>

Randriamalala, H. and Liu, Z. 2010. Rosewood of Madagascar: Between democracy and conservation. Madagascar Conservation \& Development 5, 1: 11-22. <http://dx.doi.org/10.4314/mcd.v5i1.57336>

Randrianja, S. (ed.). 2012. Madagascar, le coup d'Etat de mars 2009. KARTHALA Editions, Paris, France.

Ratsimbazafy, J. H., Ralainasolo, F. B., Rendigs, A., Mantilla-Contreras, J, Andrianandrasana, H. et al. 2013. Gone in a puff of smoke? Hapalemur alaotrensis at great risk of extinction. Lemur News 17: 14-18.

Reibelt, L. M., Woolaver, L., Moser, G., Randriamalala, I. H., Raveloarimalala, L. M. et al. 2017. Contact matters: local people's perceptions of Hapalemur alaotrensis and implications for conservation. International Journal of Primatology 38, 3: 588-608. <http://dx.doi.org/10.1007/s10764-017-9969-6>

Rendigs, A., Reibelt, L. M., Ralainasolo, F. B., Ratsimbazafy, J. H. and Waeber, P. O. 2015. Ten years into the marshes-Hapalemur alaotrensis conservation, one step forward and two steps back? Madagascar Conservation \& Development 10, 3S: 13-20. <http://dx.doi.org/10.4314/mcd.v10i1.S3>

Souchère, V., Millair, L., Echeverria, J., Bousquet, F., Le Page, C. et al. 2010. Co-constructing with stakeholders a role-playing game to initiate collective management of erosive runoff risks at the watershed scale. Environmental Modelling \& Software 25, 11: 1359-1370. <http://dx.doi.org/10.1016/j.envsoft.2009.03.002>

Stoudmann, N., Waeber, P. O., Randriamalala, I. H. and Garcia, C. 2017. Perception of change: narratives and strategies of farmers in Madagascar. Journal of Rural Studies 56: 76-86. <http://dx.doi.org/10.1016/j.jrurstud.2017.09.001>

Waeber, P. O. and Wilmé, L. 2013. Madagascar rich and intransparent. Madagascar Conservation \& Development 8, 2: 52-54 $<$ http://dx.doi.org/10.4314/mcd.v8i2.1>

Waeber, P. O., Reibelt, L. M., Randriamalala, I. H., Moser, G., Raveloarimalala, L. M. et al. 2017. Local awareness and perceptions: consequences for conservation of marsh habitat at Lake Alaotra for one of the world's rarest lemurs. Oryx. 1-10. <http://dx.doi.org/10.1017/S0030605316001198>

Wallace, A. P., Milner-Gulland, E. J., Jones, J. P. Bunnefeld, N., Young, R. et al. 2015. Quantifying the short-term costs of conservation interventions for fishers at Lake Alaotra, Madagascar. PloS ONE 10, 6: e0129440. <http://dx.doi.org/10.1371/journal.pone.0129440>

Wallace, A. P., Jones, J. P., Milner-Gulland, E. J., Wallace, G. E., Young, R. et al. 2016. Drivers of the distribution of fisher effort at Lake Alaotra, Madagascar. Human Ecology 44, 1: 105-117. <http://dx.doi.org/10.1007/s10745-016-9805-1>

White, D. D., Wutich, A., Larson, K. L., Gober, P., Lant, T. et al. 2010. Credibility, salience, and legitimacy of boundary objects: water managers' assessment of a simulation model in an immersive decision theater. Science and Public Policy 37, 3: 219-232. <http://dx.doi.org/10.3152/030234210X497726>

Wilmé, L., Waeber, P. O., Moutou, F., Gardner, C. J., Razafindratsima, O. et al. 2016. A proposal for ethical research conduct in Madagascar. Madagascar Conservation \& Development 11: 36-39. $<\mathrm{http}: / /$ dx.doi.org/10.4314/mcd.v11i1.8>

Wright, H. T. and Rakotoarisoa, J. A. 2003. The rise of Malagasy societies: new developments in the archaeology of Madagascar. In: The Natural History of Madagascar. S. M. Goodman and J. P. Benstead (eds.), pp112-119. University of Chicago Press, Chicago, USA.

* Please contact the authors for a pdf of the unpublished report.

\section{SUPPLEMENTARY MATERIAL}

Available online only.

so. General explanations on how to use the provided extra material to play the Alaotra Wetland Game.

S1. Input parameters and calculation worksheets for running scenario 1 of the Alaotra Wetland Game.

S2. Landscape.

S3. Personal Game Sheet.

S4. Market items: Farming (Rice, Onion, Vegetable).

S5. Market items: Fishing and Housing.

S6. Market items: Opportunities (Mining, Logging, Hunting).

S7. Market items: Quality of Life (Education, Health, Proteins, Electricity).

S8. Money. 